\title{
Surgical Treatment for Ureteral Complications Following Renal Transplantations
}

\section{Renal Transplantasyon Sonrası Üreteral Komplikasyonlarda Cerrahi Tedavi}

\author{
Erdal Uysal1, Mehmet Fatih Yüzbaşığlu1, Mehmet Dokur2, Mehmet Ali İkidağ3 \\ 1 Sanko University Faculty of Medicine, Department of General Surgery and Transplantation Center, Gaziantep, Turkey \\ 2 Sanko University Faculty of Medicine, Department of Emergency, Gaziantep, Turkey \\ 3 Sanko University Faculty of Medicine, Department of Radiology, Gaziantep, Turkey
}

\section{What's known on the subject? and What does the study add?}

The aim of this study was to review the causes of and surgical treatment methods for ureteral complications following renal transplantations.

\begin{abstract}
Objective

Ureteral stenosis and necrosis are the most common urological complications after a renal transplantation. Surgery is the treatment of choice in ureteral necrosis, whereas surgery, percutaneous approaches and laser endoureteromy may be applied in ureteral stenosis. The aim of this study was to review the causes of and surgical treatment methods for ureteral complications following renal transplantations.
\end{abstract}

\section{Materials and Methods}

One hundred sixty renal transplantations were performed from both cadaveric and live donors at our transplantation center between 2011 and 2014. Demographic features, complication types, surgical methods and the treatment results in 10 patients, who required surgical intervention due to ureteral complications, were recorded. Data was collected retrospectively through patient charts.

Results

Patients who were operated on because of ureteral complications were enrolled in the study. Six patients (3.75\%) had ureteral stenosis, and 4 patients $(2.5 \%)$ had ureteral necrosis. Three of these transplantations were made from living donors ( 2 female and 1 male) and 7 were from cadavers ( 1 female and 6 male). Extravasation was found in 4 patients due to necrosis, all encountered in the second week of operation. Two patients underwent native ureteropyelostomy and two underwent ureteroneocystostomy for ureteral necrosis. One patient underwent ureteroureterostomy, four had ureteroneocystostomy, and one had native ureteropyelostomy for stenosis. One patient experienced postoperative urine leakage and underwent native ureteropelvic anastomosis.

\section{Conclusion}

In our study, urological complications following renal transplantation were mostly seen after cadaveric renal transplantations. Ureteral

\section{ÖZET}

Amaç

Üreter darlığı ve nekrozu renal transplantasyon sonrası en sık görülen ürolojik komplikasyonlardır. Darlıkların tedavisinde cerrahi, perkütan girişimsel yaklaşımlar, laser endoüreterotomi gibi yöntemler uygulanabilir. Üreter nekrozlarında cerrahi tedavi ön planda yer almaktadır. Çalışmamızda merkezimizde yapılan renal transplantasyon sonrası görülen üreter komplikasyonlarının nedenlerini incelemek ve uygulanan cerrahi tedavi seçeneklerini değerlendirmek amaçlanmıştır.

\section{Gereç ve Yöntem}

2011 ve 2014 yılları arasında transplantasyon merkezimizde yapılan 160 kadavra ve canlı renal transplantasyon kayıtları retrospektif olarak değerlendirmeye alındı. Ürolojik komplikasyon nedeniyle cerrahi müdahele uygulanan 10 hastanın demografik özellikleri, gelişen komplikasyon türü, ürolojik komplikasyona uygulanan cerrahi yöntemler ve sonuçları kayıt edildi. Hastaların verilerine dosya taramaları ile ulaşıldı.

\section{Bulgular}

Üreter darlığı 6 hastada $(\% 3,75)$, üreter nekrozu 4 hastada $(\% 2,5)$ görüldü. Transplantasyonların 3'ü canlı donörden (2 kadın, 1 erkek), 7'si kadavradan (1 kadın, 6 erkek) yapıldı. İdrar kaçağı üreter nekrozundan dolayı, 4 hastada görüldü. Kaçak oluşan hastalarda kaçaklar yaklaşık 2. haftada görüldü. Üreter nekrozu nedeniyle 2 hastaya native üreteropyelostomi, diğer 2 hastaya üreteroneosistostomi uygulandı. Üreter stenozu için bir hastaya üreteroüreterostomi, 4 hastaya üreteroneosistostomi, bir hastaya native ürteropyelostomi uygulandı. Native üreteropyelostomi uygulanan hastada idrar kaçağı görüldü.

\section{Sonuç}

Çalışmamızda renal transplantasyon sonrası ürolojik komplikasyonlar en sık kadavra transplantasyonlar sonrası görüldü. Üreter stenozu en sık görülen komplikasyondu. Üriner sistem enfeksiyonları üreter

\section{Correspondence}

Erdal Uysal MD, Sanko University Faculty of Medicine, Department of General Surgery and Transplantation Center, Gaziantep, Turkey

Phone: +90 5064845803 E-mail: drerdaluysal@hotmail.com Received: 17.06.2015 Accepted: 26.06.2015 


\begin{abstract}
stenosis was the most commonly encountered complication. Urinary tract infection levels were statistically high in patients with ureteral complications. Successful outcomes were achieved in all surgical methods. Ureteroneocystostomy and native ureteropyelostomy may be preferred for treating ureteral complications in suitable patients. Choice of treatment should be determined according to the patient and cause. Large scale studies are required in order to identify which treatment is more favorable.
\end{abstract}

\section{Key Words}

Ureteral complications, renal transplantations, surgical treatment

\section{ÖZET}

komplikasyonu gelişen grupta anlamlı olarak yüksek bulundu. Uygulanan tüm cerrahi yöntemlerde başarı elde edildi. Ancak native üreteropyelostomi uygulanan bir hastada ikinci bir girişimi gerektirmeyen geçici idrar kaçağı görüldü. Hangi yöntemin daha üstün olduğunu değerlendirmek için geniş serili çalışmalara intiyaç duyulmaktadır. Üreteroneosistostomi ve native üreteropyelostomi uygun hastalarda başarıyla uygulanabilir. Tedavi seçimi hasta ve nedene bağlı olarak belirlenmelidir.

\section{Anahtar Kelimeler}

Üreteral komplikasyonlar, renal transplantasyon, cerrahi tedavi

\section{Introduction}

Ureteral stenosis and necrosis are the most common urological complications following renal transplantations, with a rate of 10 $25 \%(1,2)$. The most encountered complication seen in the long-term is stenosis (3). Ureteral complications may cause graft loss or even morbidity if not promptly treated $(4,5)$. It has been reported that ureteral revisions which are performed in the first year of transplantation have no impact on the graft functions in long-term follow-up (6).

Surgery, preventative treatments and laser endoureteromy may be performed in case of a ureteral stenosis. Surgery is the first choice of treatment in ureteral necrosis. Ureteroneocystostomy and native ureteropyelostomy are the most frequently used methods in urinary tract reconstruction.

The aim of this study was to review the reasons for surgical treatment of ureteral complications following renal transplantations that were performed in our center.

\section{Materials and Methods}

One hundred sixty renal transplantations were performed from both cadaveric and live donors at our transplantation center between 2011 and 2014. Demographic features, complication types, surgical methods used, and the treatment results in 10 patients who required surgical intervention due to ureteral complications were recorded. Data from these patients were obtained through surgical operation reports and file scans.

\section{Surgical Techniques}

\section{Donor Nephrectomy}

All living donor nephrectomies were carried out through the open donor method. Cadaveric donor nephrectomies were carried out with classic open harvesting with a liver transplantation team present. All donor nephrectomies and renal transplantations were performed by two transplantation specialists.

\section{Open Living Donor Nephrectomy}

Extraperitoneal open donor nephrectomy was performed with lumbar incision with the patient in a flank position. The ureter was dissected and released until it intercrossed with the internal iliac artery. It was then tied with a surgical polyglactin suture and cut. The renal artery was tied with a single silk strand and cut. The renal vein was cut with the help of a Satinsky clamp and the stump was sutured with 5/0 polypropylene. Donor nephrectomy was completed. The kidney was removed from the abdomen and prepared on the back table.

\section{Ureteroneocystostomy}

Ureteroneocystostomy was the most commonly used method in patients with ureteral necrosis and stenosis. Ureteroneocystostomies were performed extravesically. While the urinary bladder was full, a prolapse was created at the mucosa by inserting a detrusor muscle at the upper lateral part of the ureteral hiatus with an incision of 2-3 $\mathrm{cm}$. Afterwards, the urinary bladder was punctured with a $1 \mathrm{~cm}$ cut and an ureteral-vesical anastomosis was created using 5/0 absorbable poly (p-dioxanone) suture materials. A double-J stent was placed in all patients. The detrusor was closed by creating a tunnel.

\section{Native Ureteropyelostomy}

Native ureteropyelostomy was applied in one patient with ureteral stenosis and in two patients with ureteral necrosis. Anastomosis was performed between native ureter and graft renal pelvis by $5 / 0$ absorbable poly (p-dioxanone) suture material. Double-J catheters were placed in all patients.

\section{Ureteroureterostomy}

Due to stenosis, an end-to-end ureteroureterostomy was performed in one patient using 5/0 absorbable poly (p-dioxanone) suture materials through double-J.

The urine volume in patients, who received surgical intervention due to ureteral complications, was monitored through a Foley catheter and a vacuumed drainage system. For the first two days following the procedure, biochemistry analyses and graft functions were observed and graft vein movements were monitored through the use of Doppler imaging. Foley catheters were routinely checked once every 5 to 7 days while double-J catheters were checked on the $45^{\text {th }}$ day.

\section{Immunosuppressant Regimen}

Triple immunosuppression protocol was applied to renal transplantation recipients. Anti-thymocyte globulin (ATG) $(1.5 \mathrm{mg} /$ $\mathrm{kg}$ ) induction therapy was started and continued for 5 to 7 days in all cadaver graft recipients. Tacrolimus (TAC) or cyclosporine, mycophenolate mofetil (MMF) and prednisolone were administered to maintain immunosuppression.

Tripple immunosuppression protocol and basiliximab were started in living donor recipients. They also received MMF and prednisolone with TAC or cyclosporine. 
The initial dose of orally administered TAC was $0.15-0.30 \mathrm{mg} / \mathrm{kg}$ daily. The medicine was administered twice a day either 1 hour before meals or 2 hours after meals. As target through blood concentration, (this phrase is unclear) $12-15 \mathrm{ng} / \mathrm{mL}$ for the first month, $8-12 \mathrm{ng} / \mathrm{mL}$ for the second month, 6-10 ng/mL for the third month and 5-10 ng/mL for the duration of the treatment.

Cyclosporine was given to four diabetic patients due to uncontrolled hyperglycemia. It was switched to cyclosporine $A$ in 3 patients under TAC treatment due to hyperglycemia and in 2 patients due to TAC nephrotoxicity. The initial dose of cyclosporine A was $10-14 \mathrm{mg} / \mathrm{kg} /$ day for the first two weeks and 5-10 and 10-14 mg/kg/day were given as maintenance dosage. Drug dosages were adjusted according to cyclosporine A blood levels (C2) in the second hour of the drug intake. Cyclosporine target blood levels were maintained at C2>1500 ng/mL for 0-3 months, C2 $=1200-1400 \mathrm{ng} / \mathrm{mL}$ for $3^{\text {th }}$ month; 800-1000 $\mathrm{ng} /$ $\mathrm{mL}$ for 3-12 months, and at around $800 \mathrm{ng} / \mathrm{mL}$ after 12 months.

Mycophenolate mofetil was started within the first 72 hours after renal transplantation. Mycophenolate mofetil was given at two different daily doses at a total dose of $2 \mathrm{~g} /$ day.

Basiliximab was introduced as $20 \mathrm{mg}$ in two doses as induction therapy in living renal transplantations. The first dose was given 2 hours before renal transplantation and the second dose was applied 4 days after renal transplantation. Basiliximab was administered intravenously in $50 \mathrm{~mL}$ of normal saline within 20-30 minutes.

Methyl prednisolone was started at the dose of $15 \mathrm{mg} / \mathrm{kg}$ intravenously and reduced gradually. Oral prednisolone was administrated orally at the dose of $1 \mathrm{mg} / \mathrm{kg}$ on the fourth day. The patients were discharged on prednisolone $20 \mathrm{mg} /$ day. Five $\mathrm{mg} /$ day prednisolone was administered as a maintenance dosage.

The immunosuppressive agent of m-TOR inhibitory group was not used in any patient.

The mean follow-up period was $26.4 \pm 14.4$ (12-40) months. All graft functions are still stable and show no signs and symptoms of deterioration.

\section{Statistics}

The data obtained via analysis of the patient files were analyzed using SPSS 16.0 for Windows statistical software. The data was presented as mean \pm standard deviation (SD). A $p$ value of less than 0.05 was considered statistically significant.

\section{Results}

Six patients (3.75\%) had ureteral stenosis, and 4 patients $(2.5 \%)$ had ureteral necrosis. Three of the transplantations were made from living donors ( 2 female and 1 male), and 7 were from cadavers ( 1 female and 6 male). All patients underwent double-J stenting; the bladder capacities were between 100 and 400 cc. The duration between transplantation and the manifestation of ureteral stenosis was approximately 2 months. Extravasation due to necrosis was found in 4 patients, following the second week of operation. Two patients underwent native ureteropyelostomy and two others underwent ureteroneocystostomy for ureteral necrosis. One patient underwent ureteroureterostomy, four had ureteroneocystostomy, and one had native ureteropyelostomy for stenosis. One patient, who underwent native ureteropelvic anastomosis, had a postoperative urine leak and he was followed conservatively by drainage. Ureteral complications and treatment methods in our patients are summarized in Table 1. The comparison of the characteristics between the groups of patients, who had ureteral complication and those who did not, is given in Table 2. Characteristics of patients with ureteral complication and their donors are given in Table 3. Acute rejection attack was seen once in 2 patients with ureteral complications. With proper treatment, the rejection was decreased. Graft loss was not observed in any patients in this group.

\section{Discussion}

Ureteral complications are significant causes of hospitalization within the first year following renal transplantation. Stenosis, necrosis and urine leakage may cause liquid-electrolyte imbalance, graft loss and acute renal failure. These complications have been encountered less in recent years due to the technical progression in surgical techniques. Failure of ureter vascularisation and insufficient blood supply are assumed to be responsible for these urological complications. Excessive dissections nearby renal artery and vein may cause vascular damage and subsequent ureteral necrosis (7). It has been reported that there was no association between ureteral length and complications (8). Complication rates in ureteroureterostomy has been found to be lower than that in ureteroneocystostomy (9).

The most significant risk factors for urological complications following renal transplantation have been described as follows; old

\begin{tabular}{|c|c|c|c|c|c|}
\hline Age & Sex & Ureteral complications & Treatment & Result & Living/Cadaver \\
\hline 38 & $\mathrm{~F}$ & Stenosis & NUP & No complications & Living \\
\hline 40 & $\mathrm{~F}$ & Stenosis & UNC & No complications & Living \\
\hline 26 & $\mathrm{~F}$ & Stenosis & UNC & No complications & Cadaver \\
\hline 43 & $\mathrm{~F}$ & Stenosis & UNC & No complications & Cadaver \\
\hline 45 & M & Stenosis & UNC & No complications & Cadaver \\
\hline 42 & $M$ & Necrosis & UU & No complications & Cadaver \\
\hline 42 & M & Necrosis & UNC & No complications & Cadaver \\
\hline 34 & M & Necrosis & UNC & No complications & Living \\
\hline 22 & $F$ & Necrosis & NUP & No complications & Cadaver \\
\hline 55 & $\mathrm{~F}$ & Necrosis & NUP & Urine leak & Cadaver \\
\hline
\end{tabular}


recipients, old renal donors, male gender, recurrent transplantation, delayed renal function and lack of ureteral stenting $(5,10,11)$. There were delayed graft functions in four of our patients who had ureteral complications following cadaver renal transplantations. The mean age of the recipients was 38.7 years and ureteral stents were placed in all of our patients. Therefore, these findings were not consistent with the previous reports in the literature supporting the idea that complications were caused by other factors. For example, in a study, it was discovered that ureteral stenosis was related to multiple renal arteries, delayed graft function and advanced age (12). At first, elderly patients seemed to have a higher risk for ureteral complications. However, our study showed that there was no statistically significant difference in age between the groups of patients with and without ureteral complications. Most of the patients were middle-aged. The average age of the donors was 36.1 years.

Ureteral necrosis and urinary leakage are the most common early urological complications after renal transplantation. Persistent ureterovesical stricture is the most frequent delayed complication. Stenosis usually appears in the first two months. Although surgical techniques may take part in the etiology as well as ischemia, a recent study stated that surgical methods have less influence in the development of ureteral stenosis (13).

We encountered ureteral strictures in approximately the second month and leakage in the second week in posttransplant patients. There are numerous treatment options for ureteral strictures, including surgical reconstruction and endoscopic approach. With the advances in the interventional radiology, the necessity for surgery has been reduced in recent years, but surgical revision is still needed in many patients (2).
Yag laser endoureterotomy can be used safely and successfully in patients with posttransplant ureterovesical strictures (3). There are some reports indicating that native ureteropyelostomy can effectively be used in posttransplant strictures $(14,15)$. We successfully performed ureteroureterostomy for uretheral stenosis.

The second most common complication after stricture is ureteral necrosis along with subsequent urinary leakage. These complications require reconstruction and revision. The most preferred methods are native ureteropyelostomy and ureteroneocystostomy. We performed ureteroneocystostomy in two patients with ureter necrosis which were close to ureterovesical anastomosis. In two other patients, we chose ureteropyelostomy because of widespread ureteral necrosis.

It has been shown that there are no significant differences in longterm follow-up results between reconstruction methods performed for posttransplant urological complications (16). A study revealed that pyeloureterostomy could be a favorable method compared to ureterocystostomy in ureteral complications (17). In another study, the researchers obtained positive results by performing pyeloureterostomy after ureterovesical complications (18). Reconstruction of ureteral complications due to necrosis with pyeloureterostomy is known to be a simple and safe method (19).

Ureteral complications, especially seen after cadaveric renal transplantation, are at a rate of $2-20 \%$ on average $(20,21,22)$. However, there are studies showing that urological complications are seen in a small percentage of patients i.e. $2.8-4.9 \%(23,24)$.

In our study, the total urological complication rate was found to be $6.25 \%$. Cadaveric renal transplantations showed higher urological complication rates than did living renal transplantations. Our total

Table 2. Characteristics of the group without urological complications and the group with urological complications

\begin{tabular}{|l|l|l|l|}
\hline & No urological complication $(\mathrm{n}=150)$ & With urological complication $(\mathrm{n}=10)$ & $\mathrm{p}$ value \\
\hline Cold ischemic time (hours) & $18 \pm 6.2$ & $17.4 \pm 4$ & $>0.05^{*}$ \\
\hline Recipients age (years) & $38.7 \pm 8.4$ & $38.3 \pm 7.9$ & $>0.05$ \\
\hline Hemodialysis time (year) & $7 \pm 4.4$ & $7.8 \pm 4.6$ & $>0.05$ \\
\hline Acute rejection (graft loss) & 3 & No & \\
\hline Urinary tract infection (\%) & $16.8 \%$ & $40 \%$ & $<0.001$ \\
\hline Data was presented as mean \pm Standart deviation (SD), Cadaveric renal transplantation* & \\
\hline
\end{tabular}

Table 3. Characteristics of recipients with ureteral complications and their donors

\begin{tabular}{|c|c|c|c|c|c|c|}
\hline Recipient gender & Recipient age & Living/Cadaveric & Bladder capacity (ml) & $\begin{array}{l}\text { Hemodialysis Time } \\
\text { (year) }\end{array}$ & Donor age & Donor gender \\
\hline $\mathrm{F}$ & 38 & Living & 100 & 3 & 44 & $\mathrm{~F}$ \\
\hline $\mathrm{F}$ & 40 & Living & 200 & 2 & 36 & M \\
\hline $\mathrm{F}$ & 26 & Cadaver & 100 & 6 & 26 & M \\
\hline $\mathrm{F}$ & 43 & Cadaver & 200 & 14 & 39 & M \\
\hline M & 45 & Cadaver & 100 & 12 & 31 & M \\
\hline M & 42 & Cadaver & 200 & 9 & 40 & $\mathrm{~F}$ \\
\hline M & 42 & Cadaver & 100 & 10 & 41 & M \\
\hline M & 34 & Living & 100 & 6 & 33 & M \\
\hline $\mathrm{F}$ & 22 & Cadaver & 200 & 2 & 26 & M \\
\hline $\mathrm{F}$ & 55 & Cadaver & 100 & 14 & 45 & $M$ \\
\hline
\end{tabular}


urological complication rate was consistent with the literature data, but it was found to be a slightly higher than the average. Failure of ureteral vascularization and insufficient blood supply are assumed to be responsible for these urological complications. Excessive dissections nearby the renal artery and vein may cause vascular damage and subsequent ureteral necrosis because donors of recipients with urological complication development are advanced in age. This may be the reason for high complication rates. Keeping cold ischemia time short, not excessively dissecting especially the renal pelvis and periureteral tissue, paying attention to anastomosis technique and controlling rejections by applying suitable immunosuppressive therapy are of a great importance in reduction of urological complications (24). Placing a double-J stent also helps reduce urological complications (25).

We routinely used ureteral double-J stents in cadaveric renal transplantations. It is still a widely controversial issue whether or a not double-J stent is required in renal transplantations. We assume that the use of a double-J stent can reduce complications in cadaveric renal transplantations, kidneys with long cold ischemia times, cases of abnormal bladder, such as neurogenic, small, ureteral injury, and cases of comorbidity in the receiver.

In a study, it was stated that elongated cold ischemia duration is a high risk factor for ureteral complications in patients with diabetes mellitus (13). Another study stated that shortening the cold ischemia duration is extremely important for decreasing ureteral complications (24). In our study, no differences between the cold ischemia durations in patients with and without ureteral complications were found. Besides, no patients with ureteral complication had diabetes mellitus. These findings led us to believe that the patients in this study experienced complications for other reasons.

In our study, we have concluded that urinary tract infections were significantly common in patients with ureteral complication compared to patients without ureteral complication. Urinary tract infections may trigger an ureteral complication and ureteral complications can be results of these infections. In a study, it was concluded that urinary tract infection levels in patients with extravesical ureteroneocystostomy were high (26). When urinary infections are accompanied by urological complications, the risk of early graft loss may increase (27).

\section{Conclusion}

In our study, urological complications following renal transplantation were mostly seen after cadaveric renal transplantations. Ureteral stenosis was the most commonly encountered complication. Urinary tract infection levels were significantly high in patients with ureteral complications. Successful outcomes were achieved in all surgical methods. Ureteroneocystostomy and native ureteropyelostomy may be preferred for treating ureteral complications in suitable patients. Choice of treatment should be determined according to the patient and the cause. Large-scale studies are required in order to identify which treatment is more favorable.

Ethics Committee Approval: Ethics committee approval was not obtained due to the study was disagned as retrospectively, Informed Consent: Consent form was filled out by all participants., Concept:
Erdal Uysal, Mehmet Fatih Yüzbaşığlu, Design: Erdal Uysal, Mehmet Fatih Yüzbaşıoğlu, Mehmet Dokur, Mehmet Ali ikidağ, Data Collection or Processing: Erdal Uysal, Mehmet Dokur, Mehmet Ali ïkidağ, Analysis or Interpretation: Erdal Uysal, Mehmet Fatih Yüzbaşıŏlu, Mehmet Dokur, Mehmet Ali ikidağ, Literature Search: Erdal Uysal, Mehmet Dokur, Writing: Erdal Uysal, Mehmet Fatih Yüzbaşığlu, Peer-review: Externally peer-reviewed, Conflict of Interest: No conflict of interest was declared by the authors., Financial Disclosure: The authors declared that this study has received no financial support.

\section{References}

1. Culty $T$, Timsit MO, Neuzillet $Y$, Badet $L$, Kleinclauss F; Membres du Comité de transplantation de l'Association française d'urologie (CTAFU). Urological complications of renal transplantation. Prog Urol 2014;24:723732.

2. Dalgic $A$, Boyvat $F$, Karakayali $H$, Moray G, Emiroglu R, Haberal M. Urologic complications in 1523 renal transplantations: The Baskent University experience. Transplant Proc 2006;38:543-547.

3. Kristo B, Phelan MW, Gritsch HA, Schulam PG. Treatment of renal transplant ureterovesical anastomotic strictures using antegrade balloon dilation with or without holmium:YAG laser endoureterotomy.Urology 2003;62:831-844.

4. Lehmann K, Müller MK, Schiesser M, Wildi S, Fehr T, Wüthrich RP, Clavien PA, Weber M. Treatment of ureteral complications after kidney transplantation with native ureteropyelostomy reduces the risk of pyelonephritis. Clin Transplant 2011;25:201-206.

5. Tan EC, Lim SM, Rauff A. Techniques of ureteric reimplantation in kidney transplantation and its related urological complications. Ann Acad Med Singapore 1991;20:524-528.

6. van Roijen JH, Kirkels WJ, Zietse R, Roodnat JI, Weimar W, ljzermans JN. Long-term graft survival after urological complications of 695 kidney transplantations. J Urol 2001;165:1884-1887.

7. Król R, Ziaja J, Chudek J, Heitzman M, Pawlicki J, Wiecek A, Cierpka L. Surgical treatment of urological complications after kidney transplantation. Transplant Proc 2006:38:127-130.

8. Ali-Asgari M, Dadkhah F, Ghadian A, Nourbala MH. Impact of Ureteral length on urological complications and patient survival after kidney transplantation. Nephrourol Mon 2013; 5:878-883.

9. Nie ZL, Li OS, Jin FS, Zhang KQ, Zhu FO, Huo WO, Ma O. Urological complications in 1223 kidney transplants. Zhonghua Yi Xue Za Zhi 2009;89:1269-1271.

10. Neri F, Tsivian M, Coccolini F, Bertelli R, Cavallari G, Nardo B, Fuga G, Faenza A. Urological complications after kidney transplantation: experience of more than 1,000 transplantations. Transplant Proc 2009;41:1224-1226.

11. Alberts VP, Minnee RC, Bemelman FJ, van Donselaar-van der Pant KA, Laguna Pes $P$, Idu MM. Ureteral reconstruction after renal transplantation: clinical outcome and risk factors.Urol Int 2012;88:333-337.

12. Liu L, Ma LL, Zhao L, Zhang HX, Hou XF. Ureteral stricture following renal transplantation: risk factors and surgical management. Beijing Da Xue Xue Bao 2014;46:548-551.

13. Slagt IK, ljzermans JN, Visser $\sqcup$, Weimar W, Roodnat JI, Terkivatan T. Independent risk factors for urological complications after deceased donor kidney transplantation. PLoS One 2014;9:91211.

14. Trilla E, Lorente D, Salvador C, Planas J, Placer J, Celma A, Cantarell C, Moreso F, Seron D, Morote J. Native ureteropyelostomy in the treatment of obstructive uropathy in adult renal transplant. Experience and technical alternatives. Actas Urol Esp 2014;38:552-556.

15. Riediger $C$, Müller MW, Bachmann J, Novotny A, Thorban S, Matevossian

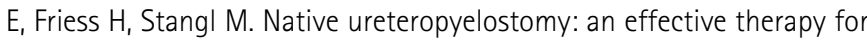
urinary tract complications following kidney transplantation. ANZ J Surg 2014;84:643-648. 
16. Hau HM, Tautenhahn HM, Schmelzle M, Krenzien F, Schoenberg MB, Morgul MH, Uhlmann D, Wiltberger G, Rasche M,Bachmann A, Jonas S, Bartels M. Management of urologic complications in renal transplantation: a singlecenter experience. Transplant Proc 2014:46:1332-1339.

17. Trapeznikova MF, Kazimirov VG, Perlin DV, Urenkov SB. A comparative evaluation of the use of pyeloureterostomy and ureterocystostomy in treating the urological complications following kidney transplantation. Urol Nefrol (Mosk) 1997;6:20-24.

18. Salomon L, Saporta F, Amsellem D, Hozneck A, Colombel M, Patard JJ, Chopin $D$, Abbou CC. Results of pyeloureterostomy after ureterovesical anastomosis complications in renal transplantation. Urology 1999;53:908-912.

19. Decurtins $M$, Vogt $N$, Largiadèr F. Secondary pyeloureterostomy after ureter necrosis in renal transplant recipients. Urol Int 1992;49:90-93.

20. Praz V, Leisinger HJ, Pascual $M$, Jichlinski P. Urological complications in renal transplantation from cadaveric donor grafts: a retrospective analysis of 20 years. Urol Int 2005;75:144-149.

21. Raman A, Lam S, Vasilaras A, Joseph D, Wong J, Sved P, Allen RD. Influence of ureteric anastomosis technique on urological complications after kidney transplantation. Transplant Proc 2013;45:1622-1624.
22. Almeida $F$, Branco $F$, Cavadas $V$, Ribeiro $S$, Osório L, Rocha $A$, Ramos M, Martins L, Castro-Henriques A, Mota C, Reis A, Fraga A. Urological complications after 134 pediatric kidney transplants: a single-center study. Transplant Proc 2013;45:1096-1098.

23. Davari HR, Yarmohammadi $H$, Malekhosseini SA, Salahi $H$, Bahador $A$, Salehipour M. Urological complications in 980 consecutive patients with renal transplantation. Int J Urol 2006;13:1271-1275.

24. Nane I, Kadioglu TC, Tefekli A, Koçak T, Ander H, Köksal T. Urologic complications of extravesical ureteroneocystostomy in renal transplantation from living related donors. Urol Int 2000;64:27-30.

25. Haberal M, Karakayali H, Sevmis S, Moray G, Arslan G. Urologic complication rates in kidney transplantation after a novel ureteral reimplantation technique. Exp Clin Transplant 2006;4:503-505.

26. Burmeister D, Noster M, Kram W, Kundt G, Seiter H. Urological complications after kidney transplantation. Urologe A 2006;45:25-31.

27. Król R, Ziaja J, Chudek J, Heitzman M, Pawlicki J, Wiecek A, Cierpka L. Surgical treatment of urological complications after kidney transplantation. Transplant Proc 2006;38:127-130. 